\title{
Inhibition of Inner Ear Ornithine Decarboxylase by Neomycin In-Vitro
}

\author{
CHARLES M. HENLEY, III, HANS-J. GERHARDT' ${ }^{1}$ AND JOCHEN SCHACHT ${ }^{2}$ \\ Kresge Hearing Research Institute, University of Michigan, Ann Arbor, MI 48109
}

Received 17 June 1986

\begin{abstract}
HENLEY, C. M., III, H.-J, GERHARDT AND J. SCHACHT. Inhibition of inner ear ornithine decarboxylase by neomycin in-vitro. BRAIN RES BULL 19(6) 695-698, 1987.- We quantitated the activity of ornithine decarboxylase (ODC) in homogenates and subcellular fractions of inner ear tissues from the rat and guinea pig and demonstrate inhibition of cochlear ODC by the aminoglycoside neomycin. Subcellular fractionation showed the enzyme associated with the postmitochondrial supernatant fraction in each of the tissues: Specific activities of ODC, defined as $\alpha$-difluoromethylornithine (DFMO)-sensitive decarboxylation of ornithine, in the supernatant fractions of combined inner ear tissues were: guinea $\mathrm{pig}=44 \pm 4$ pmoles $\mathrm{CO}_{z}$ produced/hour $/ \mathrm{mg}$ protein, and rat $=133+30$. In the guinea pig, supernatant fractions of the lateral wall tissues (stria vascularis and spiral ligament) had specific activities of $62 \pm 25$, those of the organ of Corti (plus VIIIth nerve) $64 \pm 41$. The ototoxic aminoglycoside neomycin produced a dose-dependent inhibition of ODC with half-maximal inhibition observed at $50 \mu \mathrm{M}$ drug and almost complete inhibition at $100 \mu \mathrm{M}$. This is the first report of the presence of ODC in the inner ear and its inhibition by neomycin. Since both the ODC-inhibitors, DFMO and neomycin, can cause hearing loss in patients and experimental animals it is suggested that inhibition of ODC may be an important factor in the ototoxicity of these drugs.
\end{abstract}

Ornithine decarboxylase Difluoromethylornithine Neomycin Ototoxicity Inner ear Cochlea

ORNITHINE decarboxylase (ODC), a ubiquitous enzyme regulating the biosynthesis of the polyamines putrescine, spermidine and spermine, plays a major role in cellular growth, development, maintenance and regeneration [12]. Interest in this enzyme and the polyamines in the inner ear arises from clinical observations that administration of the antitumor and antiprotozoal agent $\alpha$-difluoromethylornithine (DFMO), an irreversible inhibitor of ODC, has led to hearing loss in patients receiving the drug $[1,2,17]$. In addition, a number of observations suggest that interactions between the ototoxic and nephrotoxic aminoglycosides and polyamines may contribute to the toxicity of these drugs. For example, we have demonstrated the inhibition of renal ODC activity by aminoglycoside antibiotics (Henley et al. in preparation) and competition for polyamine transport in the inner ear [21]. In addition, the polyamines compete with aminoglycosides for renal binding and uptake $[8,9]$.

ODC has not been documented in the inner ear. Although a recent study detected the polyamines spermidine and spermine in the cochlea of rats, neither putrescine nor $O D C$ activity was found [15]. We demonstrate that ODC is present in the tissues of the rat and guinea pig cochlea and that the enzyme is inhibited in a dose-dependent manner by the ototoxic aminoglycoside neomycin.

\section{METHOD}

Sprague-Dawley rats (180-200 g; Charles River Laboratories, Wilmington, MA) or pigmented guinea pigs (approx- imately $250 \mathrm{~g}$; Murphy Breeding Laboratories, Plainsfield, IN) were briefly anesthetized with ether. Following cardiac perfusion with phosphate-buffered saline (PBS) at room temperature to flush the cochlear blood vessels the animals were decapitated and the auditory bullae removed. Each bulla was then opened to expose the cochlea. At this time the cochlea was perfused with an ice cold Ringer's solution containing $2 \mathrm{mM}$ dithioerythritol (DTE), $50 \mu \mathrm{M}$ pyridoxal phosphate (PLP) and $10 \mu \mathrm{M}$ phenylmethylsulfonylfluoride (PMSF; a protease inhibitor) from the round window to an exit hole in the apex. The cochlear bone was then removed under a dissecting microscope and the inner ear tissues dissected at $4^{\circ} \mathrm{C}$ in PBS containing $10 \mu \mathrm{M}$ PMSF.

Tissues from both the right and left ears were combined and homogenized in 60 to $140 \mu$ l of ice cold $50 \mathrm{mM}$ HEPES (N-2-hydroxyethyl-1-piperazine-N ${ }^{1}$-2-ethanesulfonic acid), $\mathrm{pH}$ 7.2, $2 \mathrm{mM}$ DTE, $50 \mu \mathrm{M}$ PLP and $10 \mu \mathrm{M}$ PMSF. The total homogenate, postmitochondrial supernatant $(13000 \times \mathrm{g}$ for 20 $\min$ at $4^{\circ} \mathrm{C}$ ) and the resuspended pelleted fractions were analyzed for ODC activity. ODC was assayed by a modification of the procedure by Russell and Snyder [13]. Aliquots $(20 \mu \mathrm{l})$ of the fractions were incubated for $60 \mathrm{~min}$ at $37^{\circ} \mathrm{C}$ in (final concentrations) $50 \mathrm{mM}$ HEPES, $\mathrm{pH} 7.2,2 \mathrm{mM}$ DTE, $0.1 \mathrm{mM}$ ethylenediaminetetraacetic acid (EDTA), $50 \mu \mathrm{M}$ PLP and $100 \mu \mathrm{M}$ L-ornithine $\left(0.25 \mu \mathrm{Ci}\right.$ to $0.5 \mu \mathrm{Ci} \mathrm{L-}\left[1-{ }^{14} \mathrm{C}\right]$ ornithine, $54.3 \mathrm{mCi} / \mathrm{mmole}$; New England Nuclear, Boston, MA), at a total volume of 50 or $100 \mu \mathrm{l}$. Incubations were terminated by the addition of $200 \mu \mathrm{l} 4 \mathrm{~N} \mathrm{H}_{2} \mathrm{SO}_{4}$ and post-incubated for $30 \mathrm{~min}$ to trap the evolving ${ }^{14} \mathrm{CO}_{2}$ on

'Permanent address: HNO-Klinik der Charité, Humboldt-Universität, Berlin, GDR.

${ }^{2}$ Requests for reprints should be addressed to $J$. Schacht. 


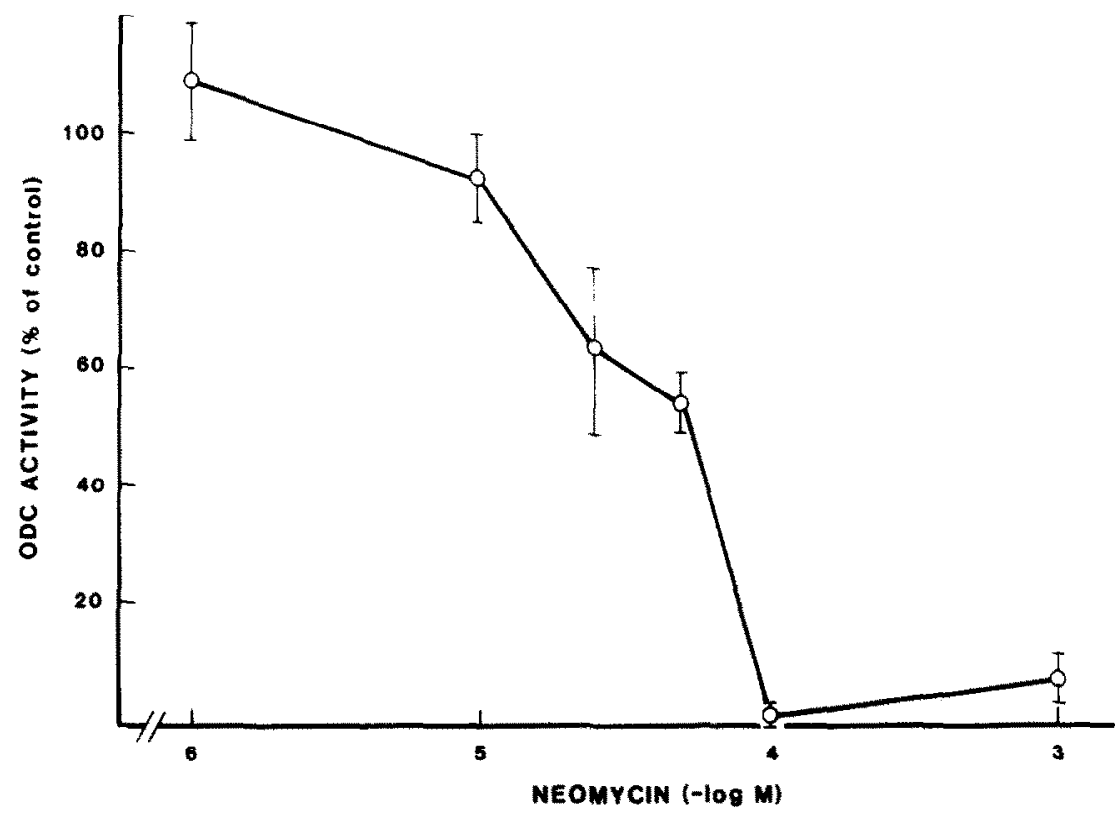

FIG. 1. Ornithine decarboxylase activity (pmoles $\mathrm{CO}_{2}$ produced/hour/mg protein) was assayed as described in the Method section in the presence of varying concentrations of neomycin. Data points represent the percent of specific activity of $O D C$ (means \pm standard errors) compared to control incubations without drug. ODC activity in the controls was $44 \pm 5$ for $n=12$ experiments in each of which duplicate or triplicate incubations were performed in parallel to those with neomycin.

filter disks saturated with $40 \% \mathrm{KOH}$. Radioactivity on the filters was quantitated by liquid scintillation counting. For each experiment, control incubations for nonenzymatic and nonspecific decarboxylation were performed by adding 500 $\mu \mathrm{M}$ DFMO (nonspecific) to the assays or substituting $20 \mu \mathrm{g}$ bovine serum albumin (BSA; nonenzymatic) for the tissue. DFMO insensitive activity (nonspecific decarboxylation) was defined as the difference in activity between incubations in the presence of DFMO and incubations with BSA. ODC activity was defined as the DFMO-sensitive decarboxylation of ornithine.

DFMO was a gift from Merrell Dow Research Institute (Cincinnati, OH). Other chemicals were purchased from Sigma Chemical Company (St. Louis, MO).

\section{RESULTS}

\section{$O D C$ Activity in Combined Inner Ear Tissues}

ODC activity was measured in homogenates and subcellular fractions of the inner ear tissues of both the rat and guinea pig. In homogenates of combined inner ear tissues, mean specific activities of $\mathrm{ODC}$ were 134 pmoles $\mathrm{CO} / \mathrm{hr} / \mathrm{mg}$ protein for the rat and 22 for the guinea pig (Table 1, last column). In addition, considerable nonspecific decarboxylation of ornithine (not related to ODC) was evident: $46 \pm 16$ in rat and $5 \pm 1$ in the guinea pig (Table $1,+$ DFMO).

Subsequent examination of subcellular fractions demonstrated that $\mathrm{ODC}$ was associated only with the postmitochondrial supernatant fraction (Table 1): $133 \pm 30$ pmoles $\mathrm{CO}_{2}$ in the rat and $44 \pm 4$ in the guinea pig and no activity in the pellet. Furthermore, nonspecific decarboxylation (+ DFMO) was negligible (rat, $2 \pm 2$; guinea pig, $0 \pm 0$ ) in the supernatant. In contrast, decarboxylation of ornithine by the resuspended pelleted fractions was not inhibited by $500 \mu \mathrm{M}$ DFMO.

\section{$O D C$ Activity in Individual Cochlear Tissues}

ODC was subsequently examined in dissected structures of the guinea pig inner ear, namely the tissues of the lateral wall (stria vascularis \& spiral ligament) and the organ of Corti (including VIIIth nerve fibers). Total homogenates as well as the supernatant and pelleted fractions were assayed (Table 1). Activity attributable to ODC in tissue homogenates was $62 \pm 5$ pmoles $\mathrm{CO}_{2} / \mathrm{hr} / \mathrm{mg}$ protein for the lateral wall and $34 \pm 10$ for the organ of Corti (Table 1, Column 3). As with the combined inner ear tissues, a considerable nonspecific decarboxylation (not sensitive to inhibition by DFMO) of ornithine was also observed (Table 1, + DFMO).

For the preparation of subcellular fractions from separated tissues six ears were pooled in order to achieve a high protein concentration. Specific activity of ODC was $62 \pm 25$ for lateral wall and $64 \pm 41$ for organ of Corti (Table 1, Column 3). Protein concentrations in assays with six pooled ears averaged $296 \mu \mathrm{g} / \mathrm{ml}$ for the lateral wall tissues and $172 \mu \mathrm{g} / \mathrm{ml}$ for the organ of Corti. Maintenance of a high protein concentration was essential since loss of ODC activity resulted 
TABLE 1

ORNITHINE DECARBOXYLASE IN COCHLEAR TISSUE

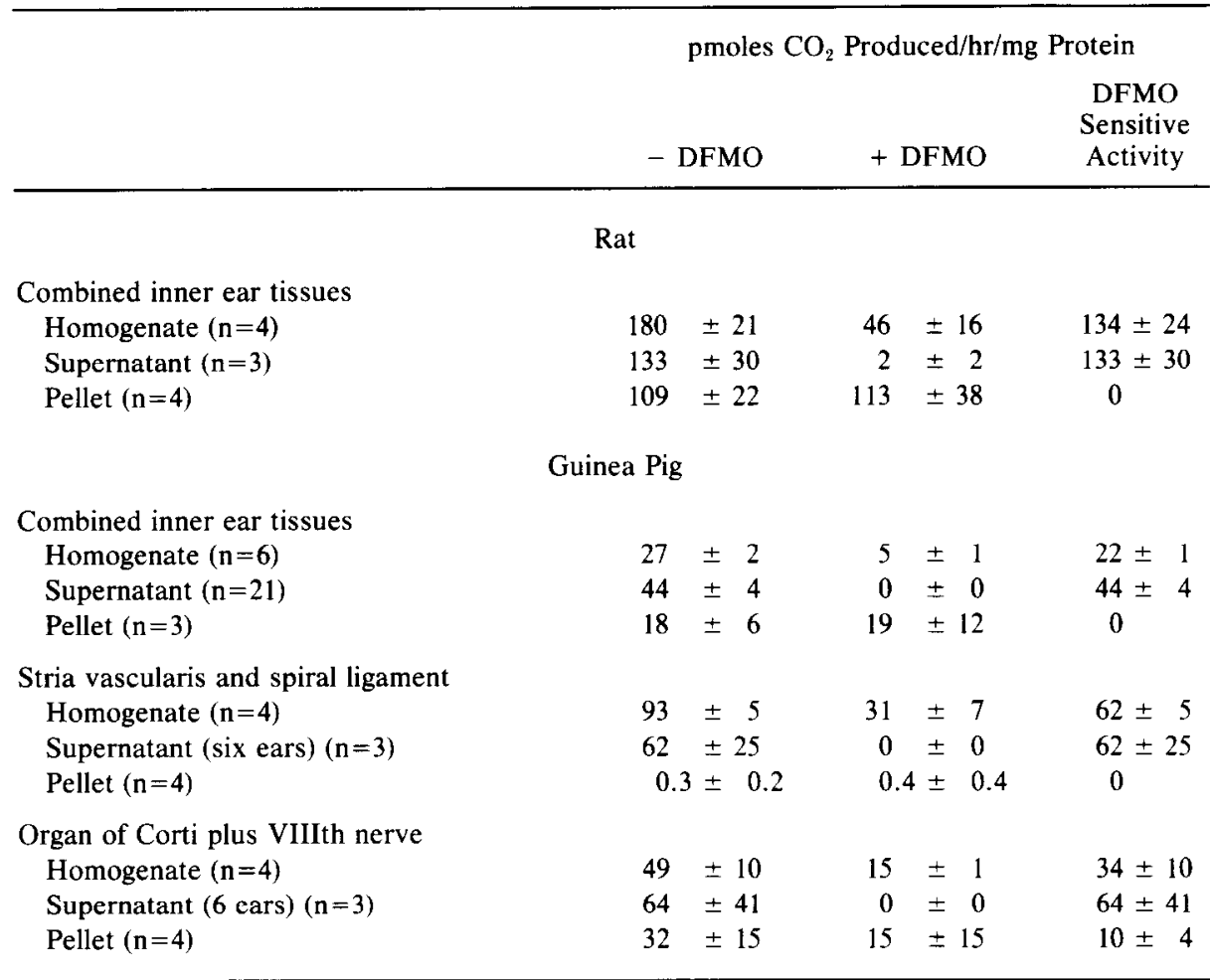

Ornithine decarboxylase activity was assayed as described in the Method section. All values are corrected for non-enzymatic decarboxylation (i.e., BSA-blanks are subtracted). ODC is defined as "DFMO-Sensitive activity," i.e., total activity (- DFMO) minus nonspecific activity (+ DFMO). Values are means \pm standard errors from $(n)$ independent experiments in which duplicate or triplicate assays were performed.

when tissues from only two pooled ears was assayed. In such a case, activity in the stria vascularis and spiral ligament was low ( $5 \pm 4$ pmoles $\mathrm{CO}_{2} / \mathrm{hr} / \mathrm{mg}$ protein) and in the organ of Corti it was nondetectable.

In agreement with the results from the combined ear tissues, no significant ODC activity was present in the pelleted fractions of the individual tissues.

\section{Neomycin Inhibition of Cochlear $O D C$}

Inhibition of ODC by neomycin was studied in the postmitochondrial supernatant fractions of combined inner ear tissues. Final concentrations of neomycin varied from 1 $\mu \mathrm{M}$ to $1 \mathrm{mM}$ and duplicate or triplicate incubations were performed in parallel with control incubations with and without DFMO. Neomycin produced a dose-dependent inhibition of cochlear ODC. Activity was reduced to $54 \pm 5 \%$ in the presence of $50 \mu \mathrm{M}$ neomycin and almost completely inhibited by $100 \mu \mathrm{M}$ neomycin.

\section{DISCUSSION}

The study clearly demonstrates the presence of ODC activity in the tissues of the inner ear of both the rat and the guinea pig. The reason why the specific activity is significantly higher in the rat remains speculative. Higher ODC activities are generally found during development but the animals used here should be considered mature. Nevertheless, age may have been a factor since preliminary studies in the young (10 and 11 days) hooded rat showed up to ten-fold higher cochlear ODC activity (Henley et al., unpublished) and the postnatal developmental pattern of ODC and polyamines in cochlear tissues has not been characterized.

Guinea pigs were chosen for the detailed studies of ODC since the species is ideally suited for surgical access to the cochlea and subsequent dissection of its tissues [4]. More importantly, the guinea pig yields greater amounts of tissue from the inner ear. For example, while combined tissues from one rat cochlea provided 12 to $33 \mu \mathrm{g}$ protein, yield from the guinea pig was two- to three-fold greater providing 58 to $80 \mu \mathrm{g}$. This is an important consideration since ODC is extremely labile in the presence of low protein concentrations $[10,12,16]$ and sensitive to dilution during all stages of purification procedures [7]. In fact, ODC activity was more consistently detected in the guinea pig than in the rat. In addition to the experiments reported in Table 1, four incubations with rat tissues (out of a total of 15) did not show activity, whereas in the guinea pig only two incubations (out of a total of 46) failed to detect ODC. The necessity for maintaining higher protein concentrations became evident again when supernatant fractions of individual tissues were assayed. These results confirm the requirement for adequate protein concentrations to stabilize the enzyme. This instability of ODC may have contributed to the inability of Schweitzer et al. [15] to detect this enzyme in the inner ear.

The clinical use of DFMO in cancer chemotherapy and aminoglycosides in the treatment of bacterial infections has 
resulted in loss of hearing. The demonstration of DFMOsensitive ODC in cochlear tissues and its inhibition by neomycin agrees well with our previous findings of aminoglycoside/polyamine antagonism [21]. It suggests that $O D C$ and polyamine-regulated cellular functions may be targets of these drugs. While the mechanism of DFMO ototoxicity is unknown, a tenable hypothesis has been offered for aminoglycoside ototoxicity [14] including a possible action on ODC. The enzyme may not necessarily be the primary site of drug action but it is suggested that drug effects on polyamine synthesis and function potentiate the injury induced by aminoglycosides. It is well established that drug-induced or other noxious insults to a target cell may result in induction of $\mathrm{ODC}$ and polyamine synthesis as part of a compensatory repair mechanism $[3,6,7,22]$. Thus, inhibition of a recovery response by the aminoglycoside itself could contribute to cell death.

A similar argument can be made for the known potentiation of noise-induced cochlear damage by aminoglycosides. Noise-induced cellular damage may be followed by induction of $\mathrm{ODC}$ in tissue recovery. Aminoglycoside inhibition of ODC would block this repair process. Another example for a possibly critical role of ODC as a drug target is the develop- ing animal. Polyamines are crucial effectors of cellular development and postnatal inhibition of ODC by DFMO has been shown to produce marked retardation of brain growth [18-20] and development of complex integrative behaviors [5]. The increased susceptibility to aminoglycoside-induced ototoxicity in the embryonic and young animal [11] may be a consequence of ODC inhibition.

While the role of ODC in drug-induced ototoxicity remains speculative the proposed mechanisms are testable and interesting in view of the crucial involvement of ODC in cellular regulation. The fact that two distinctly different ototoxic drugs inhibit this enzymatic activity is highly intriguing.

\section{ACKNOWLEDGEMENTS}

The authors wish to acknowledge the contribution of Michael Seidman in the development of the assays of cochlear tissues and Gary Zajic for assisting in dissection of cochlear tissues. We would like to thank Dr. William J. Hudak of the Merrell Dow Research Institute for providing the gift of DFMO. This research was supported by Research Grant No. NS-13792 and Training Grant No. NS-07196 from the National Institutes of Health.

\section{REFERENCES}

1. Abeloff, M., S. Rosen, G. Luk, S. Baylin, M. Zeltzman and A. Sjoerdsma. Phase II trials of $\alpha$-difluoromethylornithine, an inhibitor of polyamine synthesis, in advanced small cell lung cancer and colon cancer. Cancer Treat Rep 70: 843-845, 1986.

2. Abeloff, M. D., M. Slavik, G. D. Luk, C. A. Griffin, J. Hermann, O. Blanc, A. Sjoerdsma and S. B. Baylin. Phase I trial and pharmacokinetic studies of $\alpha$-difluoromethylornithine-an inhibitor of polyamine biosynthesis. $J$ Clin Oncol 2: 124-130, 1984.

3. Ando, M. M. Miwa, K. Kato and Y. Nagata. Effects of denervation and axotomy on nervous system-specific protein, ornithine decarboxylase, and other enzyme activities in the superior cervical sympathetic ganglion of the rat. $J$ Neurochem 42: 94-100, 1984.

4. Asarch, R., M. Abramson and W. B. Litton. Surgical anatomy of the guinea pig ear. Ann Otol Rhinol Laryngol 84: 250-255, 1975.

5. Bell, J. M., D. S. Madwed and T. A. Slotkin. Critical development periods for inhibition of ornithine decarboxylase by $\alpha$-difluoromethylornithine: Effects on ontogeny of sensorimotor behavior. Neuroscience 19: 457-464, 1986.

6. Dienel, G. A. and N. F. Cruz. Induction of brain ornithine decarboxylase during recovery from metabolic, mechanical, thermal, or chemical injury. $J$ Neurochem 42: 1053-1061, 1984.

7. Haddox, M. and D. H. Russell. Ornithine decarboxylase from calf liver. Purifications and properties. Biochemistry 20: 6721$6729,1981$.

8. Josepovitz, C., E. Pastoriza-Munoz, D. Timmerman, M. Scott, S. Feldman and G. Kaloyanides. Inhibition of gentamicin uptake in rat renal cortex in-vivo by aminoglycosides and organic polycations. J Pharmacol Exp Ther 223; 314-321, 1982.

9. Kornguth, M. L., W. H. Bayer and C. M. Kunin. Binding of gentamicin to subcellular fractions of rabbit kidney: inhibition by spermine and other polyamines. $J$ Antimicrob Chemother 6: $121-131,1980$.

10. Pegg, A. E. and H. G. Williams-Ashman. Biosynthesis of putrescine in the prostate gland of the rat. Biochem $J$ 108: 533-539, 1968.

11. Pujol, R. Periods of sensitivity to antibiotic treatment. Acta Otolaryngol [Suppl] 429: 29-33, 1986.
12. Russell, D. H. Ornithine decarboxylase: a key regulatory enzyme in normal and neoplastic growth. Drug Metab Rev 16: $1-88,1985$.

13. Russell, D. and S. H. Snyder. Amine synthesis in rapidly growing tissues: Ornithine decarboxylase activity in regenerating rat liver, chick embryo, and various tumors. Proc Natl Acad $S_{c} i$ USA 60: 1420-1427, 1968 .

14. Schacht, J. Molecular mechanisms of drug-induced hearing loss. Hear Res 22: 297-304, 1986.

15. Schweitzer, L., J. H. Casseday, A. Sjoerdsma, P. P. McCann, and $J . V$. Bartolome. Identification of polyamines in the cochlea of the rat and their potential role in hearing. Brain Res Bull 16: 215-218, 1986.

16. Seely, J. E., H. Pösö and A. E. Pegg. Purification of ornithine decarboxylase from kidneys of androgen-treated mice. Biochemistry 21: 3394-3399, 1982.

17. Sjoerdsma, A. and P. J. Schechter. Chemotherapeutic implications of polyamine biosynthesis inhibition. Clin Pharmacol Ther 35: $287-300,1984$.

18. Slotkin, T. A., F. J. Seidler, P. A. Trepanier, W. L. Whitmore, L. Lerea, G. A. Barnes, S. J. Weigel and J. Bartolome. Ornithine decarboxylase and polyamines in tissues of the neonatal rat: Effects of $\alpha$-difluoromethylornithine, a specific, irreversible inhibitor of ornithine decarboxylase. J Pharmacol Exp Ther 222: $741-745,1982$.

19. Slotkin, T. A., F. J. Seidler, W. L. Whitmore, S. J. Weigel, R. J. Slepetis, L. Lerea, P. A. Trepanier and J. V. Bartolome. Critical periods for the role of ornithine decarboxylase and the polyamines in growth and development of the rat: Effects of exposure to $\alpha$-difluoromethylornithine during discrete prenatal and postnatal intervals. Int $J$ Dev Neurosci 1: 113-127, 1983.

20. Slotkin, T. A. and J. Bartolome. Role of ornithine decarboxylase and the polyamines in nervous system development. A Review, Brain Res Bull 17: 307-320, 1986.

21. Williams, S., D. E. Smith and J. Schacht. Characteristics of gentamicin uptake in the isolated crista ampullaris of the inner ear of the guinea pig. Biochem Pharmacol 36: 89-95, 1987.

22. Yoshida, T., S. Numazawa and Y. Kuroiwa. Induction of hepatic and renal ornithine decarboxylase by cobalt and other metal ions in rats. Biochem $J$ 233: 577-581, 1986. 